Dokuz Eylül Üniversitesi-Mühendislik Fakültesi

Fen ve Mühendislik Dergisi

Cilt 20, Sayı 58, Ocak, 2018
Dokuz Eylul University-Faculty of Engineering Journal of Science and Engineering Volume 20, Issue 58, January, 2018

DOI: $10.21205 /$ deufmd. 2018205817

\title{
TCE Kaynak Zonların Yerinde Kimyasal Yıkama ile Islahı: Tween 80 ve SDS ile Yıkama Performansı
}

\author{
Seda ASLAN KILAVUZ1, Nihat Hakan AKYOL ${ }^{2 *}$ \\ 1: Kocaeli Üniversitesi, Çevre Mühendisliği Bölümü, İzmit, Kocaeli, Türkiye, \\ (ORCID: 0000-0003-3792-3549) \\ 2*: Kocaeli Üniversitesi, Jeoloji Mühendisliği Bölümü, Kocaeli, Türkiye,
}

(ORCID: 0000-0003-0389-5631)

(Alınış / Received: 21.07.2017, Kabul / Accepted: 09.10.2017,

Online Yayınlanma / Published Online: 20.01.2018)

Anahtar Kelimeler DNAPL,

Trikloroetilen,

Tween 80,

Sodyum dodeksil sülfat.
Özet: Klorlu solventler genellikle yeraltında sudan yoğun saf faz (DNAPL) olarak bulunup uzun vadede yeraltı suyu kirliliğine neden olurlar. Etkili bir ıslah performansı için, kaynak zonlarındaki saf faz kütlelerin tamamıyla uzaklaştırılması ya da kontrol edilmesi gerekmektedir. Trikloroetilen (TCE) önemli saf faz (DNAPL) kirletici gruplarından olup yer altı sularında sıkça karşılaşılmaktadır. Çalışma kapsamında, heterojen jeolojik sistemlerde hapsolmuş olan TCE kaynak zonlarının Tween 80, Sodyum dodeksil sülfat (SDS) ve su ile yerinde islah performansının başarısı incelenmiștir. Heterojen jeolojik ortamın yansıtılması amacıyla farklı tane boyundaki kuvars kumları kullanılmıștır. Bu kapsamda bir seri 2 boyutlu akım hücresi deneyleri yürütülerek hedeflenen sonuçlara ulaşılması planlanmıştır. Çalışma sonucunda; matriks ve düşük geçirgenlikteki zonların içerisinde bulunan saf faz TCE kütlesi yıkama ajanlarının etkisiyle tamamıyla (su ile yıkama hariç) ıslah edilmiştir. Kullanılan yıkama solüsyonları içerisinde en iyi ıslah performans siralamasi, Tween $80>$ SDS $>$ su ile yıkama olarak belirlenmiştir. Teknolojinin başarısı özellikle DNAPL dağılımı, yıkama solüsyonu türü ve derișimi ve fiziksel ortam heterojenliğinden önemli oranda etkilenmektedir. Sonuç olarak, arazi çalışmalarında teknolojinin başarısı sahaya özgü olup, bu durum kirlenmiş sahalarda etkili DNAPL islah teknolojilerini karakterize etmede oldukça önemlidir

\section{In-Situ Remediation of TCE Source Zones by Chemical Flushing: Performance of Tween 80 and SDS}

\section{Keywords}

DNAPL,

Trichloroethylene,

Tween 80,
Abstract: Chlorinated solvents exist as dense non-aqueous phase liquids (DNAPL) in the subsurface and generally lead to long term groundwater contamination. For effective remediation performance, DNAPL mass in the source zone must be controlled 
Sodium dodexyl sulfate.

or eliminated. Trichloroethylene (TCE) is one of the most important DNAPL phase and widespread groundwater contaminant. In this study, reagent enhanced remediation of residual TCE resided in heterogeneous geological setting using Tween 80, Sodium dodecyl sulfate (SDS) and water was examined. Silica sand media with different median particle diameters were used to represent physical heterogeneity. 2-D Flow-cell experiments were conducted for the objectives. Results showed that residual TCE sources resided in matrix and low-K zones were completely removed due to the effects of solubilization agents (Except water flooding). Performance of reagents on TCE source zone remediation was found to be in the following order: Tween $80>$ SDS $>>$ Water. The performance of remediation technology was affected by distribution of DNAPLs, type and concentration of reagent and the presence of physical heterogeneity. As a result, the performance of technology depends on the site characteristics which are critical to characterize effective DNAPL remediation strategies for contaminated sites.

*Sorumlu yazar: nakyol81@yahoo.com

\section{Giriş}

Klorlu solventler önemli DNAPL kirletici gruplarından olup metal sanayinde ve havacılıkta yağ çözücü, kuru temizlemede ve elektronik sanayi gibi birçok alanda kimyasal solvent olarak kullanılmaktadır. Klorlu solventler yeraltına çoğunlukla DNAPL (Dense nonaqueous phase liquids) olarak girerler. DNAPL'ların yeraltındaki hareketi DNAPL miktarına, özelliğine, fiziksel ortam özelliklerine ve akım koşullarına bağlıdır[1]. Yeterli miktarda DNAPL mevcudiyetinde, su tablasından aşağıya doğru hareketine geçirgenliği düşük bir katmanla karşılaşıncaya kadar devam eder [2]. Doygun zonda DNAPL kütlesinin bir kısmı suda çözünmeye başlarken bir kısmı ise matriks içerisinde (küçük gözeneklerde) hapsolarak hareketsiz kalabilir.

Diğer kısmı ise akifer sisteminin tabanını oluşturan geçirimsiz kil ya da ana kaya içerisinde veya üzerinde depolanmaktadır. Bu kütleler özellikle bu noktalarda DNAPL birikintileri oluşturmakta olup, uzun vadede yer altı su kaynakları için potansiyel bir risk oluşturmaktadır (Şekil 1).
Trikloroetilen (TCE) yeraltı suyu akifer sistemlerinde en çok gözlenen klorlu organik bileșiklerden biridir. TCE'nin sudaki çözünürlülüğü çok düşük olmasına rağmen $(\sim 1300 \mathrm{mg} / \mathrm{L})$, içme suyundaki müsaade edilen sınır değeri (5 $\mu \mathrm{g} / \mathrm{L})$ ile karşılaştırıldığında göreceli çözünürlülüğü oldukça yüksektir. Dolayısıyla, yeraltında çok az miktarlarda bulunsalar dahi, çözünmüş faz TCE üretme potansiyeline sahip olup, büyük hacimlerde yeraltı su kütlelerini kirletme riski oldukça yüksektir.

Özellikle DNAPL kaynak zonlarının yayılımını engelleyerek kontrol altına alacak ya da temizleyecek teknolojilerin uygulanması oldukça önemlidir. DNAPL'lar ile kirlenmiș akiferlerin temizlenmesinde yillarca geleneksel pompala ve arit (pump and treat) teknolojisi uygulanmıștır. Organik kirletici kütlesinin saf fazdan çözünmüş faza geçiş kinetiğinin çok yavaş olması, kirliliğin pompala ve arıt gibi yöntemlerle temizleme süresini uzatmakta ve DNAPL kütlesini ortamdan tamamen uzaklaştırmak için oldukça yüksek hacimlerde su ile yıkama gerektirmektedir [3]. 


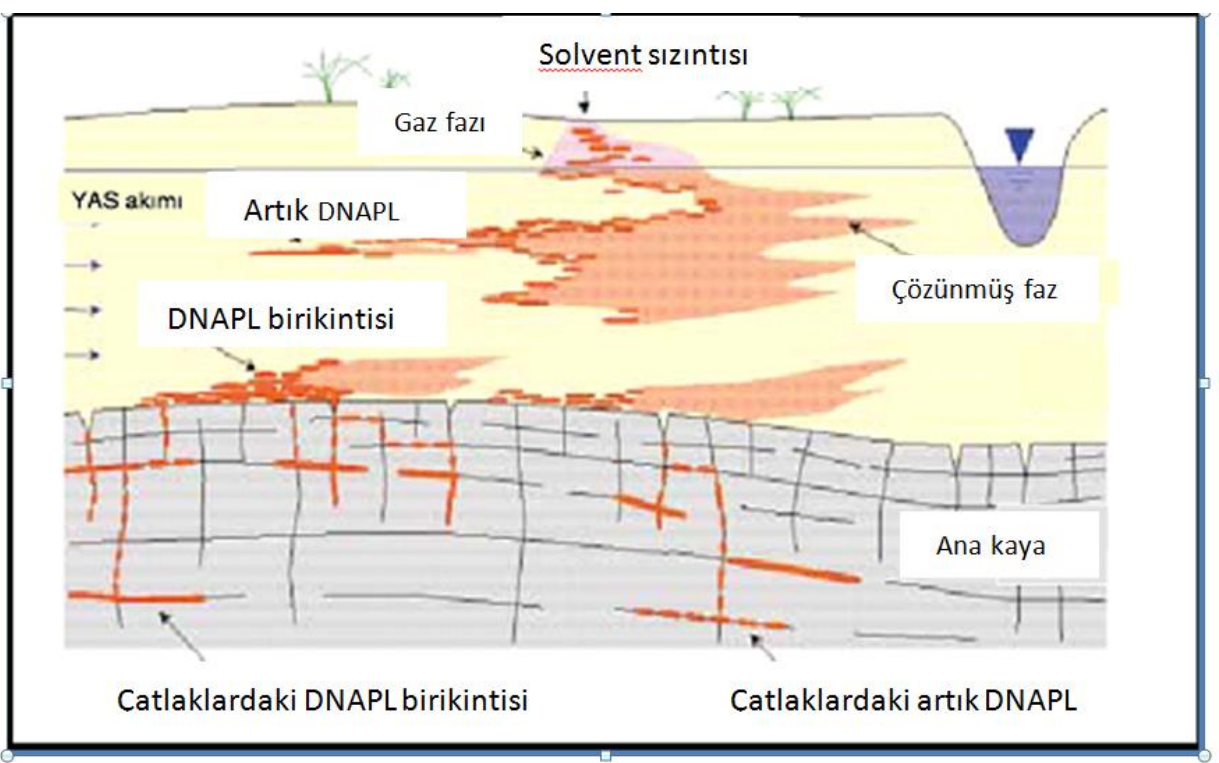

Şekil 1. Akifer içerisinde DNAPL taşınımı ve dağılımı (Pankov ve Cherry, 1996)

$\mathrm{Bu}$ durum 'pompala ve arit teknolojisinin' yer altı sularında DNAPL kirliliğinin temizlenmesindeki performansının zayıf olduğunu işaret etmiş ve alternatif arıtma teknolojilerinin geliştirmesi gerekliliğini doğurmuştur.

Yerinde kimyasal yıkama teknolojisi (YKYT), akiferlerin kaynak zonlarındaki DNAPL kütlelerini uzaklaştırmada kullanılan önemli ıslah teknolojilerinden biridir. Bu teknolojide yüzey aktif madde, alkol, kosolvent yada kompleks şekerler gibi kimyasalların suya ilavesi ile DNAPL'ların çözünürlüğü arttırılarak ve yüzey gerilimi azaltılarak su ile yıkamaya göre daha etkin bir uzaklaştırma sağlanmaktadır [4-11]

DNAPL çözünümü ve DNAPL kütlelerinin depolandığı fiziksel ortamın durumu 'yerinde kimyasal yıkama teknolojisi (ISCF)" ve "Pump and Treat" metodunu yansitan laboratuar ve arazi uygulamalarında da belirgin bir şekilde gözlenmiştir. Diflippo vd. (2010) tasarladı̆̆ı farklı boydaki kuvars kumlarından oluşturulan heterojen jeolojik sistemlerde, geçirimsiz birim üzerinde yer alan DNAPL fazındaki TCE gölcüğün, Tween 80 yüzey aktif maddesi ile ıslahı test edildiğinde; fiziksel ortam özelliğinden ve çözünmenin kinetikle sinırlı olmasından dolayı ıslah performansı etkilendiğini belirtmiştir [7]. Akyol vd. (2013); yansıttığı 2 farklı heterojenlikte SDS yüzey aktif maddesinin, DNAPL fazındaki TCE'nin dağılımının ve yıkama hızının etkisinin ıslah performansına olan etkisini incelediğinde; özellikle fiziksel ortamın tabanını oluşturan düşük geçirgenlikli birim içerisinde birikinti şeklinde depolanan TCE kütlesinin ıslahının matrikse oranla daha yavaş ve uzun sürmekte olduğunu belirlemiștir [9]. Bu gibi hidrolik olarak elverişli olmayan zonların mevcudiyetinden kaynaklanan ideal olmayan davranış, ortamda yıkama ajanlarının olmadığı, doğal fiziksel ortam malzemelerinde $[12,13]$ ve yüzey aktif madde yerine kompleks şeker kullanılan benzer farklı çalışmada da gözlenmiştir [11]. Yukarıda bahsedilen çalışmalarda genelde tek tür yıkama ajanı kullanılmaktadır. Özellikle, literatürde geniş ölçekte kullanılan farklı türdeki yüzey aktif maddelerin aynı fiziksel ortam koşullarında 
incelenmesi, ıslah ajanı seçimi için oldukça önemlidir [ 7,9$]$.

Yapılan çalışmanın amacı; heterojen karakterdeki akifer sisteminin yansıtıldığı 2 boyutlu akım hücresi deneyleri ile farklı karakterde depolanmıș olan DNAPL TCE kütlelerinin 2 farklı yüzey aktif madde (SDS, Tween 80) ile yıkanarak yerinde ıslah performansını karşılaștırmalı değerlendirmektir. Ayrıca, bir adet deney saf su ile tekrar edilerek "Yüzey Aktif Madde" ile Ylkama metodunun "Pompala ve Arıt" yöntemiyle karşılaştırılması amaçlanmıştır.

\section{Materyal ve Metot}

\subsection{Fiziksel ortam ve çözeltiler}

Akım hücresi deneyleri kapsamında farklı türdeki fiziksel ortam heterojenliğini yansıtmak amacıyla farklı tane boyundaki silis kumları kullanılmıștır. $359 \mu \mathrm{m}$ (40/50 mesh) ve $172 \mu \mathrm{m} \quad(70 / 100$ mesh $)$. Hidrolik İletkenlik (K) değerleri $40 / 50$ ve 70/100 mesh kumlar için sırasıyla 70 ve $7 \mathrm{~cm} /$ saat olarak ölçülmüştür. 40/50 mesh kum geçirimli, 70/100 mesh kum ise geçirimsiz tabanı temsil etmektedir. Seçilen fiziksel ortam malzemeleri diğer çalışmalarda da kullanılmıştır [7,9]. Sudan IV ile boyanmış olan TCE, model kirletici olarak kullanılırken sodyum dodeksil sülfat (SDS) ve Tween 80 yıkama çözeltileri olarak kullanılmıştır. Bu kimyasallar haricinde bir adet deney seti saf su ile tekrar edilmiștir. Hidrodinamik akım koșullarının belirlendiği reaktif olmayan izleyici taşınımı deneyleri için penta floro benzoik asit (PFBA) kullanılmıştır. PFBA diğer çalışmalarda da geniş ölçekte kullanılan izleyici türüdür.

\subsection{Akım hücresi deneyleri}

Gözenekli ortamın farklı noktalarında depolanan DNAPL TCE kütlelerinin farklı türdeki yıkama çözeltileri (Tween 80, SDS) ve su ile islah performansının değerlendirilmesi 2 boyutlu akım hücresi deneyleriyle amaçlanmıştır (Tablo 1).

Deneylerde kullanılan iki boyutlu akım hücre sistemi paslanmaz çelikten, ön ve arka yüzü ise DNAPL dağılımının gözlemlenebilmesi için cam malzemeden yapılmıştır (Şekil 2). Hücrenin üst kısminda sol, sağ ve orta noktasına DNAPL enjeksiyonuna olanak sağlayacak girişler yapılmıştır. Hücrenin sol ve sağ yanına solüsyon giriș ve çıkışı sağlayacak enjeksiyon delikleri açılmıştır. Hücrenin iç kısmına enjekte edilen çözeltinin daha iyi yayılmasını sağlayacak paslanmaz çelik bir filtre $(12 \mu \mathrm{m})$ yerleștirilmiștir. Hücrenin girişi paslanmaz çelik boruyla peristaltik pompasına bağlanırken çıkışında ise bir örnek alma yapısı oluşturulmuştur. Akım hücresi deneyleri kapsamında farklı türdeki fiziksel ortam heterojenliğini yansitmak amacıyla farklı tane boyundaki silis kumu kullanılmıștır. (40-50 mesh ve 70100 mesh). Düșük geçirgenlikteki tabanı temsil eden 70-100 mesh kum, hücrenin tabanını oluştururken üzerine matriksi temsil eden 40/50 mesh kum eklenmiștir (Şekil 2).

Fiziksel ortam heterojenliği yansıtıldıktan sonra akım hücresi suya doygun hale getirilmiştir. Suya doyurma işlemini takiben, fiziksel ortam içerisinde oluşan hidrodinamik akım koşullarını belirlemek amaciyla PFBA testi yapılmıştır. Bu test için $500 \mathrm{mg} / \mathrm{L}$ PFBA çözeltisi hücreye enjekte edilmeye başlanmıștır. Hücre çıkıșındaki PFBA konsantrasyonu başlangıç konsantrasyonuna eşit olduktan sonra hücre tekrar saf su ile yıkanarak PFBA sistemden uzaklaştırılmıştır. Deneyden elde edilen PFBA değișim grafikleri (PV$\mathrm{C} / \mathrm{Co}$ ) standart zamansal moment analizi yardımıyla incelenerek PFBA kütle dengesi ve gecikme katsayısı belirlenmiştir. C/Co hücre çıkışından 
alınan örneğin konsantrasyonunun (C) başlangıç konsantrasyonuna (Co) olan oranıdır.

PFBA testini takiben, yıkama ajanları ile TCE'nin ıslahı amacıyla 5 adet akım hücresi deneyi yürütülmüștür. İlk iki deney Tween 80 ile yürütülmüștür. İlk deneyde, fiziksel ortam içerisindeki matrikse $(40 / 50$ mesh $)$ ve ince malzemeden oluşan çanağın $(70 / 100$ mesh) üzerine yarı yarıya toplam $2,5 \mathrm{ml}$ DNAPL TCE hücrenin orta noktasindan enjekte edilip yaklaşık 48 saat süreyle beklenilmiștir.

Tablo 1. Akım hücresi deney koșulları

\begin{tabular}{|c|c|c|c|c|c|}
\hline $\begin{array}{c}\text { Akım } \\
\text { hücresi } \\
\text { deneyleri }\end{array}$ & $\begin{array}{c}\text { Gözenek suyu } \\
\text { hızı }\end{array}$ & Ajan Türü & $\begin{array}{c}\text { DNAPL } \\
\text { kütlesi }\end{array}$ & $\begin{array}{c}\text { TCE Ekleme } \\
\text { Noktası }\end{array}$ & $\begin{array}{c}\text { TCE } \\
\text { Giderim }\end{array}$ \\
\cline { 2 - 6 } Deney 1 & 7,2 & \% & g & - & $\%$ \\
\hline$\underline{\text { Deney 2 }}$ & 7,2 & $\begin{array}{c}\% 5 \text { Tween } \\
80\end{array}$ & 3,6 & $\begin{array}{c}1,8 \text { g matriks }+ \\
1,8 \text { g orta çanak }\end{array}$ & 99,8 \\
\hline$\underline{\text { Deney 3 }}$ & 7,2 & $\%$ 5 SDS & 3,6 & $\begin{array}{c}1,8 \text { g matriks }+ \\
1,8 \text { g orta çanak }\end{array}$ & 100,1 \\
\hline Deney 4 & 7,2 & $\%$ 2,5 SDS & 3,6 & $\begin{array}{c}1,8 \text { g matriks }+ \\
1,8 \text { g orta çanak }\end{array}$ & 100,8 \\
\hline$\underline{\text { Deney 5 }}$ & 7,2 & Su (Kontrol) & 3,6 & $\begin{array}{c}1,8 \text { g matriks }+ \\
1,8 \text { g orta çanak }\end{array}$ & 62.4 \\
\hline
\end{tabular}

*Bu deney setinde matrikse yapılan TCE enjeksiyonu $0,9 \mathrm{~g}$ sol ve $0,9 \mathrm{~g}$ orta enjeksiyon deliklerinden olacak șekilde toplam 1,8 g yapılmıștır.

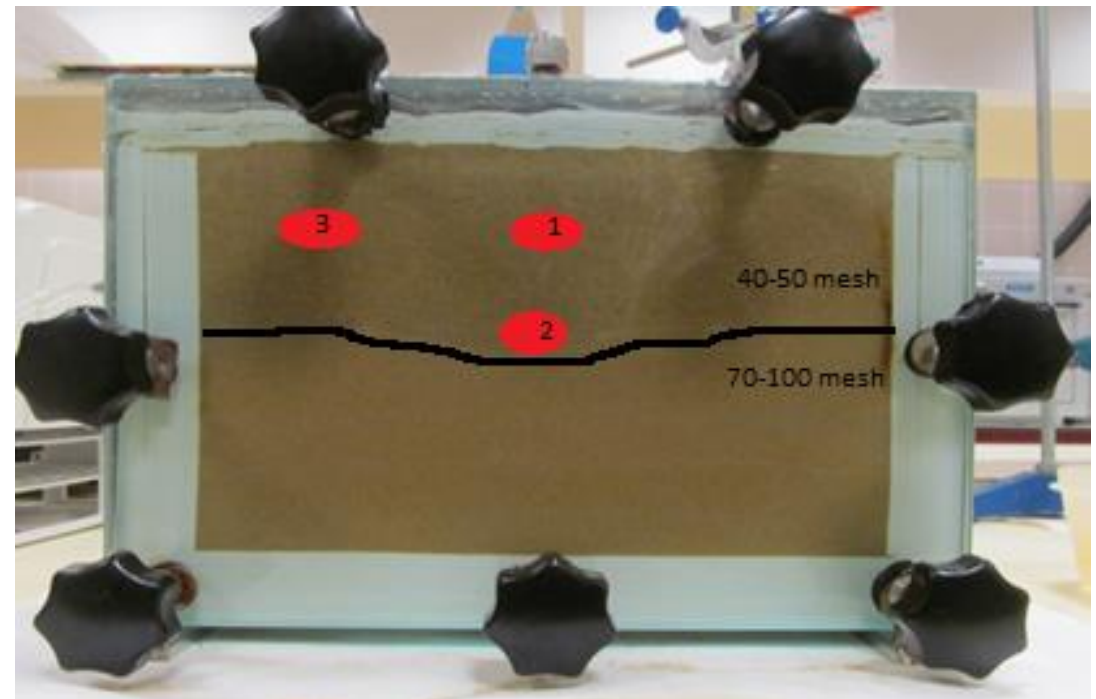

Şekil 2. İki boyutlu akım hücresi düzeneği. 1 ve 3 nolu enjeksiyonlar matrikse, 2 nolu enjeksiyon çanağa yapılan enjeksiyonu temsil etmektedir. 3 nolu enjeksiyon sadece 2. deney setinde sol delikten matrikse yapılan enjeksiyonu temsil etmektedir.

Bu süre sonunda, $\% 5$ lik Tween 80 ile 7,2 $\mathrm{cm} / \mathrm{saa}$ gözenek suyu hızında devamlı olarak hücreye enjekte edilmiştir. İkinci deneyde ise, aynı hacimli DNAPL TCE'nin bir kısmı orta delikten alttaki $(1,25 \mathrm{ml})$ çanağın $(70 / 100$ mesh $)$ 
üzerine, geriye kalan kısmı ise hücrenin sol ve orta enjeksiyon deliği vasitasıyla (40/50 mesh) matrikse iki eşit hacimde $(0,63$ 'er $\mathrm{ml})$ enjekte edilmiştir. Birinci ve ikinci deney setleriyle, TCE dağılımının ıslah performansina olan etkisinin belirlenmesi amaçlanmıștır. Üçüncü, dördüncü ve beşinci deneylerde TCE enjeksiyonları birinci deney koşullarında belirtildiği gibi gerçekleştirilmiştir. Üçüncü ve dördüncü deneylerde sırasıyla SDS çözeltisi sırasıyla $\% 5$ ve $\% 2,5$ olarak kullanılırken 5. deneyde saf su kimyasal yıkama deneylerine kontrol amaçlı kullanılmıştır. Bu deney setleriyle DNAPL TCE'nin gözenekli ortam içerisindeki uniform olmayan dağılımı, yıkama ajanının türü ve konsantrasyonunun ıslah yöntemine olan etkisi incelenmiştir. Bütün deneylerde hücre çıkış suyundaki TCE konsantrasyonu $1 \mathrm{mg} / \mathrm{L}$ 'nin altına inince deneyler sonlandırılmıștır. \%5'lik SDS deney setinde üç farklı zamanda fotoğraf çekilerek DNAPL TCE dağılımının yıkama sırasındaki değişimi gözlenmiştir.

Deneyler esnasında zamana bağlı olarak numuneler alınarak TCE konsantrasyonları ölçülmüştür. $\mathrm{Bu}$ deneylerdeki C/Co oranı ise TCE'nin hücre çıkışındaki anlık konsantrasyonun (C) TCE'nin çözünürlük değeri olan 1300 $\mathrm{mg} / \mathrm{L}$ (Co) ye olan oranıdır. Örnekleme periyodunu temsilen boyutsuz zamanı ifade eden PV [ ] kullanılmıștır. 1 PV fiziksel ortam içerisinde akan suyun kendini yenilemesi için gerekli olan süredir. Bu süre 2,3 saat olarak belirlenmiştir.

Deneylerden elde edilen TCE değişim grafikleri (breakthrough grafikleri) standart zamansal moment analizi yardımıyla incelenerek deneylerde izlenen bileşiklerin kütle dengeleri çıkartılmıştır. Moment analizlerinde sıfırıncı moment $\left(\mathrm{M}_{\mathrm{o}}\right)$ kolonu terk eden kütle miktarını vermektedir. Deneylerin kütle dengesi, enjekte edilen kütleden kolonu terk eden kütlenin çıkartılmasıyla elde edilmiştir.

Moment analizlerinde 1. düzeltilmiş moment $\left(\mathrm{M}_{1}{ }^{*}\right)$ PFBA kütlesinin gecikme katsayısını vermektedir. Sıfırıncı moment ve birinci düzeltilmis normalize moment eşitlikleri aşağıda sunulmuştur.

$$
\begin{aligned}
& M_{o}=\int_{0}^{t} c d t \\
& M_{1}=\int_{0}^{t} c t d t \\
& M_{1}^{*}=\frac{M_{1}}{M_{0}} \\
& R=M_{1}^{*}-0,5 t_{0}
\end{aligned}
$$

Bu formüllerde $M_{0}=0$. moment; $M_{1}$ : 1 . zamansal moment $M_{1}{ }^{*}=1$. zamansal normalize moment, $C$ : konsantrasyon t: zaman, $t_{0}=$ enjeksiyon süresini temsil etmektedir

PFBA ve TCE konsantrasyonları sirasıyla 262 ve $200 \mathrm{~nm}$ dalga boyunda UV-VIS Spektrofotometre ile ölçülmüştür.

\section{Bulgular}

\subsection{Reaktif olmayan PFBA izleyici} taşınımı

Yaratılan fiziksel ortam içerisindeki hidrodinamik akım koşullarının belirlemesi amacıyla suya doygun ortam koşullarında reaktif olmayan izleyici deneyi gerçekleştirilmiştir. Şekil 3'te görüldüğü gibi PFBA izleyici deneylerinden elde edilen gecikme katsayısının 1'den biraz fazla olması $(R=1,05)$ olması ve PFBA grafiklerinin yükselim ve elüsyon kısımlarının 
nispeten asimetrik olması, izleyicinin ideal olmayan bir taşınım davranışı gösterdiğini işaret etmektedir. Bu husus, gözenekli ortamda var olan bazı zonlara giren suyun o noktalarda belirli süre kalmasından kaynaklanmaktadır. $\mathrm{Bu}$ zonlar özellikle, 70/100 mesh düşük geçirgenlikteki tabanın üzerinde bulunan çanaktan ve matriksi temsil eden 40/50 mesh kumdan kaynaklanmaktadır. İzleyici deney sonuçları, topraktaki akımın ayrıca advektif ve belirli oranda dispersif karakterli olduğunu göstermektedir. Bu durum gözenekli ortamin DNAPL kütlelerinin depolanması açısından heterojen karakterde olduğunu göstermektedir.

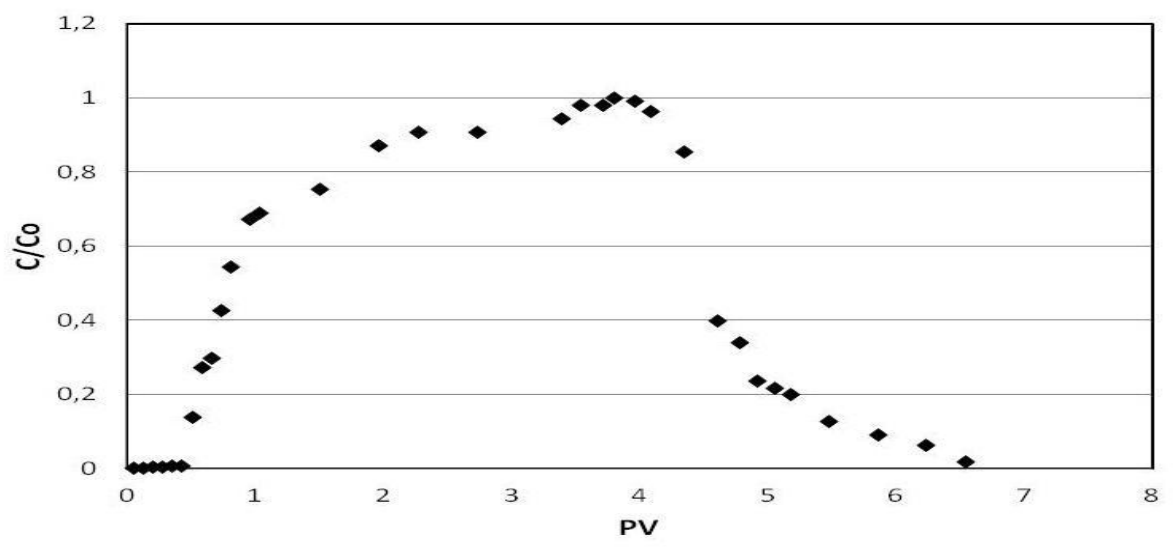

Şekil 3. Akım hücresi deneyi ile PFBA yükselim-azalım grafiği

\subsection{DNAPL TCE'nin farklı yıkama ajanları ile ıslah performansının incelenmesi}

\subsubsection{Tween 80 ile yıkama}

$\%$ 5'lik Tween 80 ile yıkama deney setleri iki farklı organik solvent dağllımında yürütülmüștür. Birinci deneyde; fiziksel ortam içerisindeki üst matrikse ve daha ince malzemeden oluşan alt matrikse toplam 2,5 ml DNAPL TCE yarı yarıya enjekte edilip yaklașık 48 saat süreyle beklenilmiștir. $\mathrm{Bu}$ süre sonunda, \%5 lik Tween 80 çözeltisi devamlı olarak hücreye enjekte edilmiștir. Deney sırasında TCE'nin zamana bağlı değişimi Şekil 4'te görülmektedir. Tween 80 enjeksiyonun başlaması ile TCE konsantrasyonu hızlı bir şekilde artarak yaklaşı 6 saat sonunda en yüksek değer olan 6100 mg/L'ye ulaşmıștır. Bu değer TCE'nin çözünürlük değerinin yaklaşık 5 katı olup, Tween 80 yüzey aktif maddesinin TCE'nin çözünürlüğünü artırmasından kaynaklanmaktadır. Bu değer daha sonra azalmaya başlamıştır. 13 saat sonunda TCE konsantrasyonu $2000 \mathrm{mg} / \mathrm{L}$ civarında duraylılığa ulaştıktan sonra yaklaşık 6-7 saat bu değerlerde gözlenmeye devam etmiştir. $\mathrm{Bu}$ süre sonunda TCE konsantrasyonu dramatik bir șekilde azalmakta olup 16 saat sonunda tamamen hücreden uzaklaştırılmıştır.

İkinci deneyde aynı hacimdeki $(2,5 \mathrm{ml})$ DNAPL TCE kütlesi 70/100 mesh kumun ve üzerindeki $40 / 50$ mesh kum 
matriksinin içerisine paylaştırıldı ve 48 saat beklendikten sonra yine \%5'lik Tween 80 ile yıkanmıștır. Birinci deneyden farkı matriks (40/50 mesh) içerisine yapılan enjeksiyon sol ve orta enjeksiyon delikleri yardımıla yarı yarıya yapılmasıdır. $\mathrm{Bu}$ deney setin amacl, DNAPL TCE'nin farklı noktalardaki dağılımının ıslah performansına olan etkisini incelemektir. $\mathrm{Bu}$ deneyde, Tween 80 enjeksiyonun başlaması ile TCE konsantrasyonu hızlı bir şekilde artarak yaklaşık 3,5 saat sonunda en yüksek değer olan 7300 mg/L'ye ulaşmıştır (Şekil 4). Bu değer daha sonra azalmaya başlamıştır. 5 saat sonunda TCE konsantrasyonu 2000 $\mathrm{mg} / \mathrm{L}$ civarında duraylılığa ulaştıktan sonra yaklaşık 6-7 saat bu değerlerde gözlenmeye devam ettikten sonra 11. saatin sonunda TCE ortamdan tamamen uzaklaşmıştır. DNAPL kütlelerinin matriks içerisinde farklı noktalarda depolanmasının ıslah performansına etkisi Şekil 4'te görülmektedir. İkinci deneyde, depolanan DNAPL kütlesinin yaklaşı 5 saat daha önce ıslah edilmesi, hücrenin sol üst enjeksiyon noktasından eklenen belirli miktar TCE'nin Tween 80 ile kısa sürede buluşmasından ve hızlı bir şekilde çözünmesinden kaynaklanmaktadır. Her iki deney setinde de TCE konsantrasyon artışını takiben bir azalım ve duraylılığa erişme gözlenmiştir. İdeal olmayan bu davranışın nedeni; matriks içerisindeki çözünmenin hızlı olup düşük geçirgenlikli tabandaki çözünmenin ise nispeten yavaş olmasından kaynaklanmakta olup islah performansını olumsuz yönde etkilemektedir.

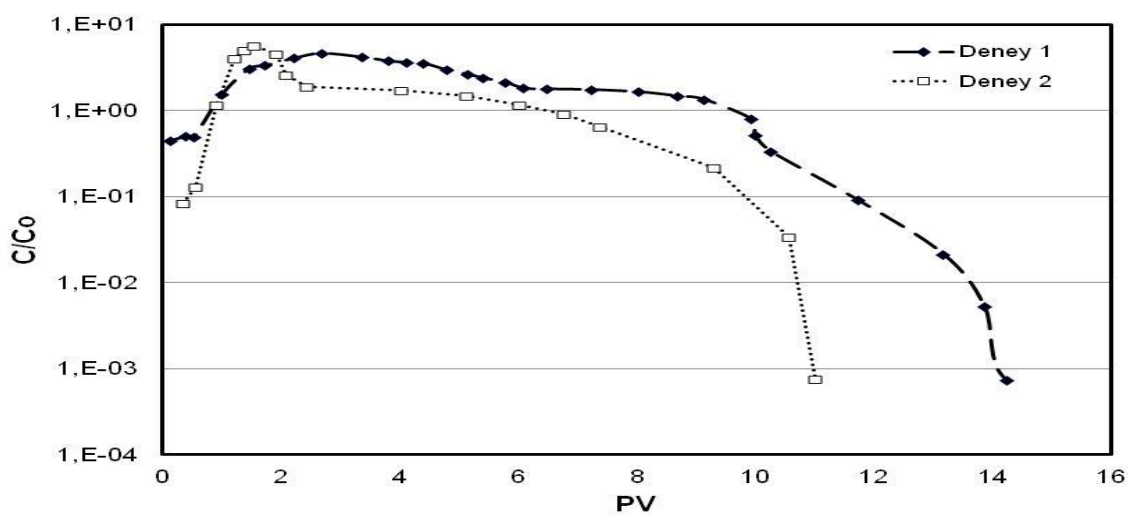

Şekil 4. Tween 80'li Yıkama ile TCE’nin zamana bağlı değişimi. (1 PV= 2,3 saat)

\subsubsection{SDS ile yıkama}

Yürütülen 2 adet deney setinde; 2 farklı SDS yüzdesi (\% 2,5 ve 5) DNAPL TCE kütlesinin ıslahında kullanılmıştır (Şekil 5). Hücrenin ortasındaki enjeksiyon noktasından fiziksel ortam içerisindeki matrikse $(40 / 50)$ ve ince malzemeden $(70 / 100)$ oluşan çanağa toplam $2,5 \mathrm{ml}$ DNAPL TCE yarı yarıya enjekte edilip yaklaşık 48 saat süreyle beklenilmiştir. $\mathrm{Bu}$ süre sonunda, $\% 5$ ve $\% \quad 2,5$ SDS çözeltisi ayrı deneyler olacak şekilde devamlı olarak hücreye enjekte edilmiştir.

\%5'lik SDS'in kullanıldığı ilk deneyde; ilk 20 saatte 20/30 mesh kum matriksinin içerisinde depolanan DNAPL TCE'nin ilk olarak hızlı bir şekilde çözünmesi (DNAPL fazından çözünmüş faza geçiş) ile TCE konsantrasyonu hızlı bir şekilde artarak yaklaşık 7 saat sonunda en yüksek değer olan 7030 mg/L'ye ulaşmıştır /Şekil 5). Bu değer daha sonra azalmaya başlamıştır. 20. ve 28. saatleri 
arasinda daha ince taneli 70/100 mesh kum matriksinin içerisindeki DNAPL TCE'nin daha yavaș hızda çözünmesi sonucu duraylı TCE konsantrasyonu gözlenmiştir. Yaklaşık 40 saat sonunda sistemdeki tüm TCE kütlesi hücreden uzaklaștırılmıștır.

\% 2,5 SDS'in kullanıldığı ikinci deneyde ise; yaklaşı 11 saatte TCE konsantrasyonu en yüksek değer olan $4400 \mathrm{mg}$ /L'ye ulaşmıștır (Şekil 5). 34. ve 61. saatleri arasında 70/100 mesh kum matriksinin içerisindeki DNAPL TCE'nin daha yavaş hızda çözünmesi sonucu duraylı TCE konsantrasyonu gözlenmiştir. Yaklaşık 68 saat sonunda tüm TCE kütlesi hücreden uzaklaştırılmıştır. Sonuç olarak, Yüksek SDS yüzdesi (\%5) kullanıldı̆̆ında; TCE kütlesinin tamamıla hücre içerisinden uzaklaştırılması yaklaşı 28 saat daha kısa sürmektedir. SDS deneyleri sonuçlarına bakıldığında Tween 80'e göre TCE kaynak zonlarının ıslahı daha uzun sürmüștür (Șekil 7). Bu durum saha çalışmalarında uygun yıkama ajanı (SDS ya da Tween 80) seçiminde dikkatle incelenmelidir. Ayrıca, Tween 80 deneylerinde gözlenen ideal olmayan çözünme davranışı SDS deneylerinde daha da belirgin şekilde gözlenmiştir. Hidrolik olarak elverişli olmayan zonu temsil eden düşük geçirgenlikli taban içerisindeki DNAPL TCE kaynak zonlarının ileri zamandaki ıslahı üçüncü deney setinde alınan fotoğraf görüntüsünde de teyit edilmiștir (Șekil 6). Benzer durum diğer çalıșmalarda da gözlenmiștir $[7,9,11]$.

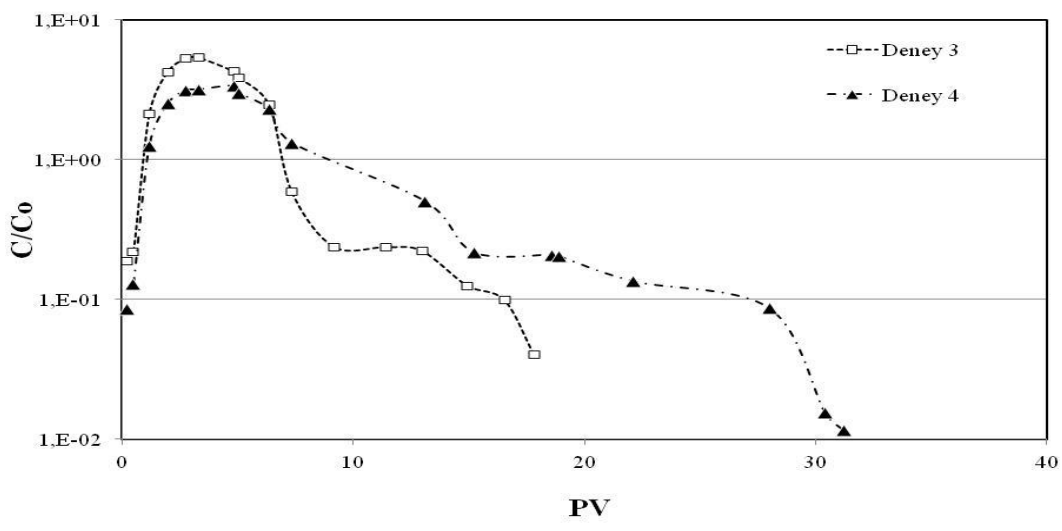

Şekil 5. SDS'li Yıkama ile TCE’nin zamana bağlı değişimi. (1 PV= 2,3 saat) 

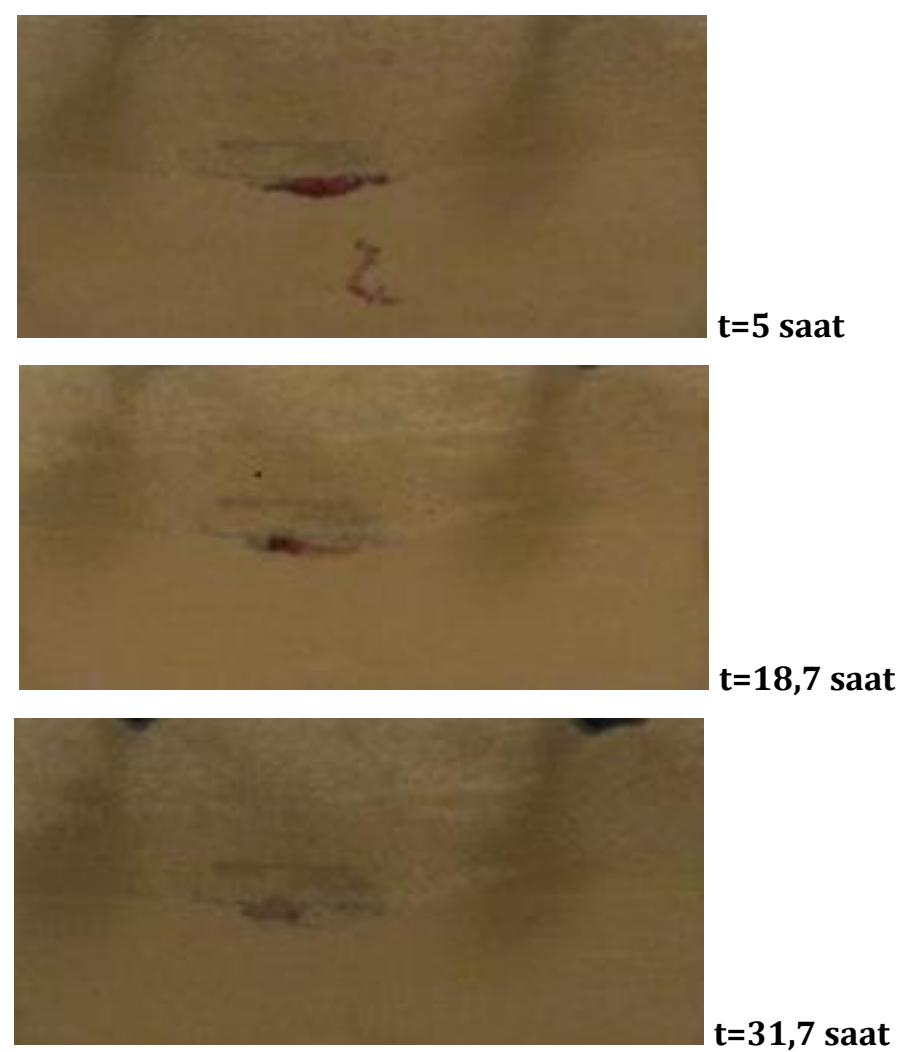

Şekil 6. SDS ile yıkama sırasında DNAPL TCE’nin zamana göre dağılımı (Deney 3).

\subsubsection{Su ile yıkama}

Hücrenin ortasındaki enjeksiyon noktasından fiziksel ortam içerisindeki matrikse $(40 / 50)$ ve ince malzemeden (70/100) oluşan çanağa toplam $2.5 \mathrm{ml}$ DNAPL TCE yarı yarıya enjekte edilip yaklaşık 48 saat süreyle beklenilmiştir. $\mathrm{Bu}$ süre sonunda, saf su devamlı olarak hücreye enjekte edilmiştir. Yaklaşık 7 saatte TCE konsantrasyonu en yüksek değer olan $856 \mathrm{mg} /$ L'ye ulaşmıştır (Şekil 7). 10. ve 60. saatleri arasinda 40/50 mesh kum matriksinin içerisindeki DNAPL TCE'nin daha yavaş hızda çözünmesi sonucu TCE konsantrasyonu yavaş bir şekilde azalarak $100 \mathrm{mg} / \mathrm{L}$ seviyelerine erişmiştir. Daha sonra düşük geçirgenlikteki taban $(70 / 100$ mesh) içerisindeki TCE kaynak zonlarının oldukça yavaş çözünmesi nedeniyle oldukça uzun süre TCE konsantrasyonu değişimi $100 \mathrm{mg} / \mathrm{L}$ seviyelerinde kalmıștır. Yaklașık 140 saat sonunda bu deney sonlandırılmıştır. Sonuç olarak hidrolik olarak elverişli olmayan zonlarda $\quad(70 / 100$ mesh $)$ depolanan DNAPL TCE kütlelerinin ıslah hızı Tween 80>SDS $>$ su olarak belirlenmiștir. 


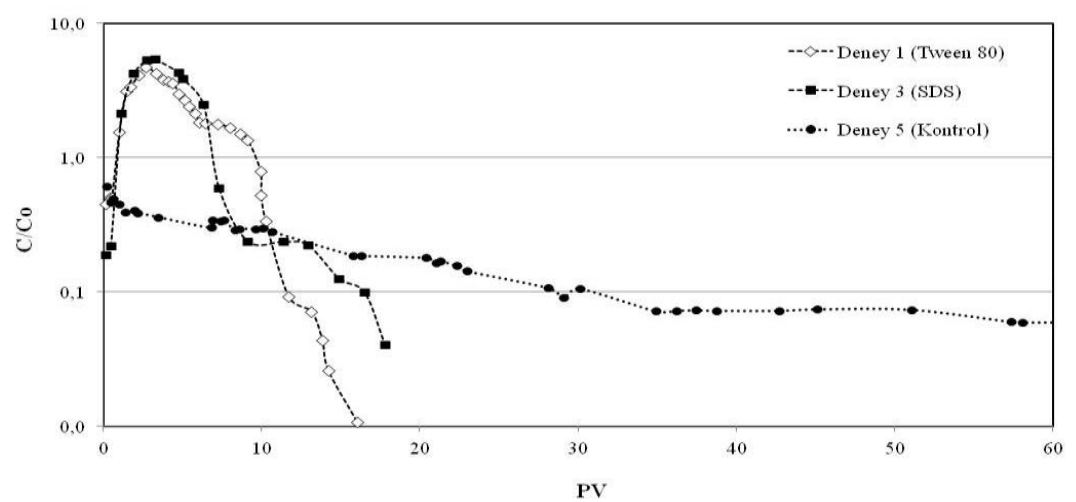

Şekil 7. Tween 80, SDS ve Su ile Yıkama ile TCE’nin zamana bağlı değişimi. (1 PV= 2,3 saat)

\section{Tartışma ve Sonuç}

Klorlu bileşiklerden trikloroetilen, tehlikeli atık sahaların çoğunda gözlenebilmektedir. $\mathrm{Bu}$ tür bileşikler çoğunlukla akiferlerin tabanında, DNAPL birikintisi şeklinde depolanabilmektedir. Yeraltında bulunan suda çözünmeyen organik bileşiklerin uzun dönem kirletici kaynağl olduğu ve uygulanan saha ıslahının maliyetini ve ıslah süresini önemli derecede artırdığı bilinmektedir. Çalışma kapsamında, yürütülen bir seri 2 boyutlu akım hücresi deneyleriyle DNAPL TCE, yaratılan fiziksel heterojen jeolojik malzeme içerisindeki düzensiz dağılımının, çözünürlüğü artırıcı kimyasallı (SDS ve Tween 80) yıkama ile ıslah performansına olan etkisi incelenmiștir. Ayrıca, bir adet deney saf su ile tekrar edilerek kimyasal yıkama teknolojisinin performansı "Pompala ve Arıt" teknolojisi ile karşılaştırılmıştır. Sonuç olarak; tüm deneylerde (Su ile yıkama hariç) TCE kütlesinin tamamı uzaklaştırılmasına rağmen, elde edilen sonuçlar neticesinde Tween 80'nin sslah performansı en başarılı olup, onu sirasıyla SDS ve su izlemektedir. Tween 80, SDS ve saf su deneylerinde test edildiği gibi; DNAPL TCE kütlelerinin farklı noktalardaki düzensiz dağılımının, yıkama ajan (Tween 80, SDS ya da su) ve konsantrasyonlarinın islah performansına olan etkisi belirgindir. Özellikle, tüm deneylerde gözlendiği gibi, fiziksel ortamın tabanını olușturan düşük geçirgenlikli birim üzerinde birikinti şeklinde depolanan TCE kütlesinin ıslahı matrikse oranla daha yavaş ve uzun sürmekte olduğu belirlenmiştir. $\mathrm{Bu}$ durum özellikle TCE'nin zamana bağlı değişim grafiklerinde belirli süre boyunca gözlenen duraylı TCE konsantrasyonları ile gözlemlenmektedir. Bu gibi hidrolik olarak elverişli olmayan zonların mevcudiyeti ve bu gibi çalışmalardan elde edilen bilgiler, saha çalışmaları sırasında kullanılması planlanan yıkama ajanlarının seçiminin belirlenmesi açısından oldukça önemlidir. Seçilen yıkama ajanlarının konsantrasyon larının mümkün olduğunca düşük olması ile yıkama ajanından kaynaklı kirliliğe engel olması hedeflenirken, seçilen ajan dozu ile TCE konsantrasyonlarının izin verilen limitlerin (TCE için $5 \mu \mathrm{g} / \mathrm{L}$ ) altına inmesi ıslah verimi için önemli unsurlardır. Bu hususlar göz önünde bulundurulduğunda, hem saha ıslah performansının iyileşmesine hem de süre ve maliyetin azalmasına önemli oranda katkı sağlanacaktır.

\section{Teşekkür}

Çalışma, TÜBİTAK 3001 Proje No: 115Y117 tarafından desteklenmiştir. 


\section{Kaynakça}

[1] Feenstra, S., Cherry, J.A., 1988. Subsurface contamination by dense non-aqueous phase liquid (DNAPL) chemicals. International Groundwater Symposium, The International Association of Hydrogeologists, Halifax, Nova Scotia.

[2] Mercer, J.W., Cohen, R.M., 1990. A review of immiscible fluids in the subsurface: Properties, models, characterization and remediation. J. Contam. Hydrol., 6: 107-163. DOI: 10.1016/0169- 7722(90)90043-G

[3] Mckay D. J., Stark J. A., Young B. L., Govoni J. W., Berini C. W., Cronan T. J., Hewitt T. J. 2000. "A field demonstration of trichloroethylene oxidation using potassium permanganate". Proceedings of the Second International Conference on Remediation of Chlorinated and Recalcitrant Compounds, Monterey, CA, USA, 109-116.

[4] Boving, T.B., Brusseau, M.L. 2000. Solubilization and removal of residual trichloroethene from porous media: Comparison of several solubilization agents. J. Contam. Hydrol, 42: 51-67. DOI: 10.1016/S0169-7722(99)00077-7

[5] Tick, G.R., Lourenso, F., Wood, A.L., Brusseau, M.L., 2003. Pilot-scale demonstration of cyclodextrin as a solubility-enhancement agent for the remediation of a tetrachloroethene-contaminated aquifer. Environ. Sci. Technol., 37: 5829-5834. DOI: 10.1021 /es030417f

[6] Tick, G., Rincon, E., 2009. Effect of enhanced solubilization agents on dissolution and mass flux from uniformly distributed immiscible liquid trichloroethylene (TCE) in homogeneous porous media. Water, Air and Soil Pollut., 204: 315-332.
[7] Difilippo, E.L., Carroll, K.C., Brusseau, M.L. 2010. Impact of organic-liquid distribution and flow-field heterogeneity on reductions in mass flux. J. Contam. Hydrol. 115: 14-25. DOI: 10.1016/j.jconhyd.2010.03.002

[8] Harvell J.R., 2012. Solubilization of Multi-component immiscible liquids in homogeneous systems: A Comparison of different flushing agents using a 2-D flow-cell. M. Sc. Thesis, University of Alabama, 83s.

[9] Akyol, N.H., Russo A.L., Brusseau, M.L. 2013. Impact of EnhancedFlushing Reagents and Organic Liquid Distribution on Mass Removal and Mass Discharge Reduction. Water Air and Soil Pollut., 224:17-31.

[10] Tick G. R., Harvell J.R., Murgulet D., $2015 . \quad$ "Intermediate-Scale Investigation of EnhancedSolubilization Agents on the Dissolution and Removal of a Multicomponent Dense Nonaqueous Phase Liquid (DNAPL) Source", Water, Air and Soil Pollut., 204, 315-332.226-371.

[11] Turkkan S., Akyol N.H., 2017. Cyclodextrin-Enhanced In-situ Flushing of TCE Source Zones Resided in Heterogeneous Porous Media, International Journal of Advances in Science, Engineering and Technology (IJASEAT)., 5, Iss-2, Spcl Iss-1 (P-I).

[12] Russo, A.E., Mahal, M.K., Brusseau, M.L., 2009. Nonideal behavior during complete dissolution of organic immiscible liquid: 1 . Natural porous media. J. Hazard Mater., 172: 208-213.

[13] Mahal, M.K., Murao, A., Johnson, G.R., Russo, A., Brusseau, M.L. 2010. Non-ideal behavior during complete dissolution of organic immiscible liquid: 2. Ideal porous media. Water, Air, Soil Pollut., 213: 191-197. 